\title{
HILGARDIA
}

A Journal of Agricultural Science Published by the California Agricultural Experiment Station

CONTENTS

DENSITY AND

ARRANGEMENT OF VINES

FREDERIC T. BIOLETTI

AND

A. J. WINKLER 


\title{
$\begin{array}{lllllllll}H & \text { I } & \text { L } & G & \text { A } & \text { R } & \text { D } & \text { I } & \text { A }\end{array}$
}

A Journal of Agricultural Science Published by

the California Agricultural Experiment Station

\begin{tabular}{lll}
\hline VoL. 8 & APRIL, 1934 & No. 6 \\
\hline
\end{tabular}

\section{DENSITY AND ARRANGEMENT OF VINES ${ }^{1}$}

\author{
FREDERIC T. BIOLETTI ${ }^{2}$ AND A. J. WINKLER ${ }^{3}$
}

The DENSITY of viNes in the vineyard, or ratio of population to unit area, varies greatly in the various grape-growing regions of the world. The arrangement, or relation of position of the individual vines to each other, varies in a similar way. The density ranges from about 10,000 to the acre in Champagne to about 200 in Almeria. The arrangement varies from promiscuous (irregular) to various regular systems, of which the most common are forms of the rectangular (square and avenue). The hexagonal system, formerly common, is little used now in California.

Density.-What is the most suitable population depends upon many conditions-soil, climate, water supply, character of available labor, and the capacity for growth of the variety of vine. Conditions which restrict the growth of the vine-ecological factors or the intrinsic nature of the vine-usually require the greater densities to insure full acre yield. In Champagne and regions of similar cool climate close planting is believed to promote shallow rooting and thereby to be favorable to the early ripening of the grape. On the other hand, the more favorable the climate, the more fertile the soil, and the greater the capacity of the variety for growth, the less the density should be. Where these favorable conditions exist, close planting results in a crowding and interlacing of the canes and a dense shade of foliage which interferes with the setting, growth, coloring, and ripening of the fruit, increases the difficulty of control of fungus and insect enemies of the vine, and makes cultivation and harvesting unduly costly.

The water supply - from rain or irrigation-is also a limiting factor. If it is deficient, a small number of vines may succeed where a larger number competing for the inadequate supply would fail to yield profit-

1 Received for publication September 15, 1933.

2 Professor of Viticulture and Viticulturist in the Experiment Station.

3 Associate Professor of Viticulture and Associate Viticulturist in the Experiment Station; Professor Winkler is joint author of the plan of the experiment on which this paper is based. He also collected the data with the able assistance of Giovanni Barovetto, vineyard foreman. 
able crops. Where water is the limiting factor, it may be exhausted by a dense population before the crop has matured.

Arrangement.-The most advisable arrangement of the vines is determined by the methods of cultivation used, the system of training and harvesting adopted, and by what appears to give the most perfect utilization of the soil. Where most or all of the cultivation is done by hand, as in Champagne, the promiscuous arrangement is satisfactory. For densities of 5,000 or more this is the only practical method, but for densities of less than 3,000 most of the cultivation can be facilitated by the use of draft animals and in this case a regular arrangement of the vines is necessary. Where mechanical tractors are used, the density with the square system cannot conveniently be more than 700 , while for greater economy and with large implements it must be reduced to 500 or even 300 . With the avenue system where the vines are trellised and cultivated in only one direction somewhat greater densities may be used.

Density and Arrangement.-What is the best combination of density and arrangement for any particular set of circumstances can be determined only by long experience or by carefully conducted experiments. When found, it will be a compromise decided by the quantity and quality of the resulting crops and the cost of the various cultural and harvesting operations. The costs of production per acre and per ton will generally decrease with decrease of density up to an optimum for the particular conditions, owing to the saving of hand labor by the use of machines, and at the same time the quality of the crop may be improved by the more favorable aeration and insolation of the fruit. The quantity of the crop will, on the other hand, increase with the increase of density up to a certain point, which varies with the other factors discussed. The quantity will be greatest with the arrangement which enables the vines to utilize the soil area most effectively.

Of the various arrangements, it is generally considered that the hexagonal system is most favorable to the early and complete utilization of the soil and the wide avenue system the most unfavorable. This consideration is based on the assumption that a young vine spreads its roots equally to all points of the compass. If this assumption is correct, the periphery of the root system will be a circle. This circle will enlarge until it meets the corresponding circles of the adjoining vines. This, it is further assumed, brings about competition, and further extension is stopped or retarded. When this theoretical point is reached with the hexagonal system, the root circles of the vines occupy 91 per cent of the soil area. With the square system, they will occupy only 79 per cent, and with the avenue system they will occupy a percentage increasingly less as the difference between the width of the avenues and the distance 

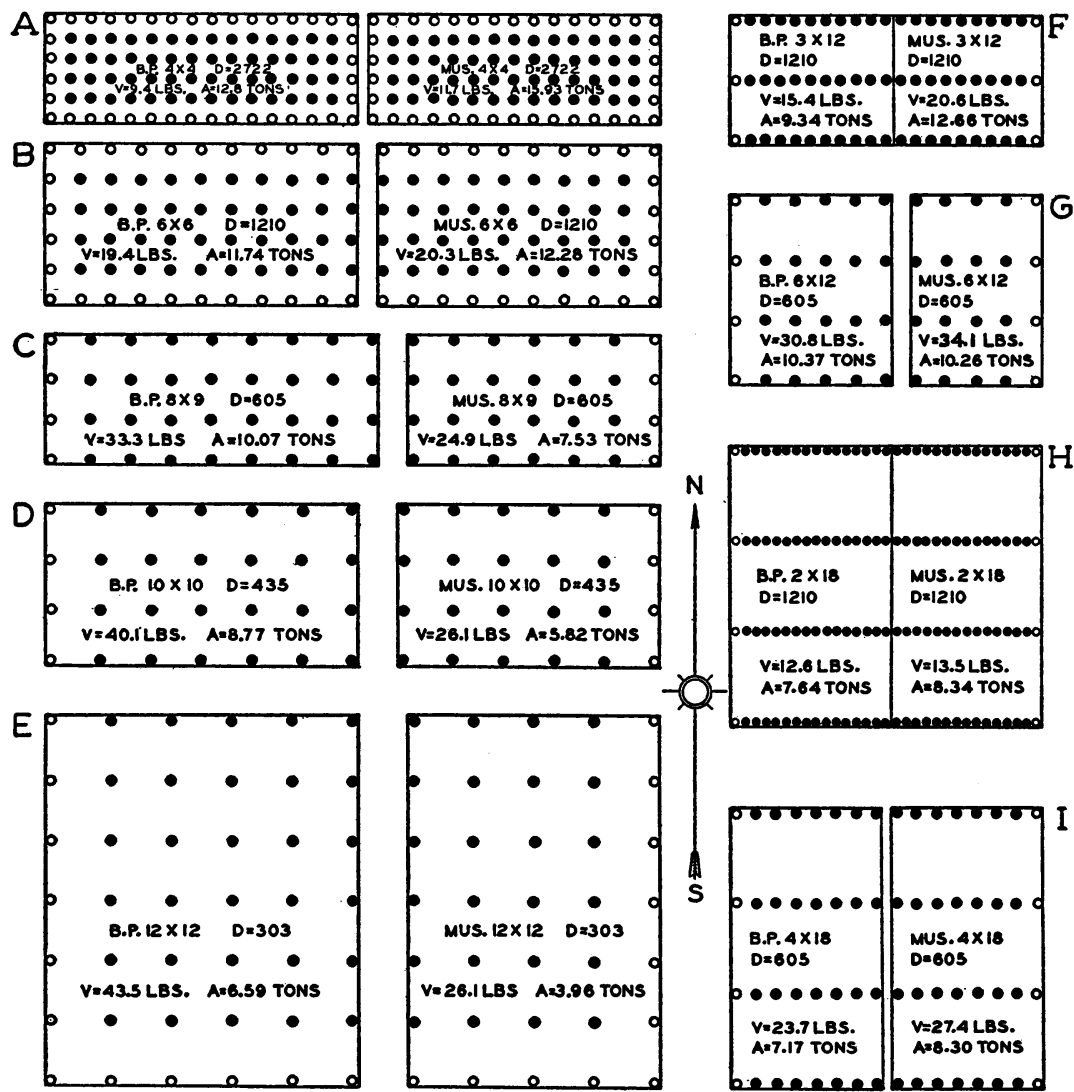

E

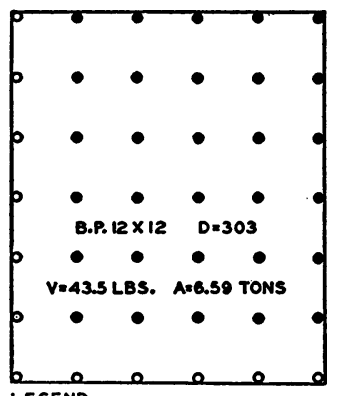

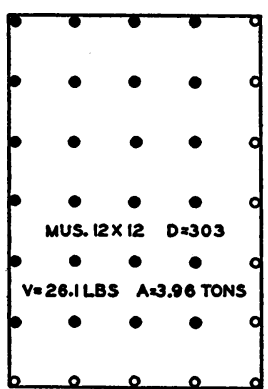

$A=10.26$ TONS

O=VINES INCLUDED, O=VINES EXCLUDED, B.P.=BLACK PRINCE, MUS.=MUSCAT, D=DENSITY, V=POUNDS PER VINE, A-TONS PER ACRE.

Fig. 1. Plan of the density and arrangement vineyard. The yields given are means of the crops of 1926,1927 , and 1928 .

TABLE 1

HYPOTHETICAL UTILIZATION OF SoIL WITH VARIOUS ARRANGEMENTS OF VINES

\begin{tabular}{|c|c|c|}
\hline \multirow{2}{*}{ Arrangement and distance in feet } & \multicolumn{2}{|c|}{$\begin{array}{c}\text { Hypothetical utilization of soil at the } \\
\text { beginning of competition }\end{array}$} \\
\hline & Formula used* & Per cent \\
\hline Hexagonal.. & $O \div T=\pi \div 2 \sqrt{3}$ & 90.69 \\
\hline Square............ & $O \div T=\pi \div 4$ & 78.54 \\
\hline 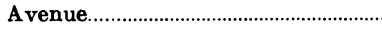 & $O \div T=\pi r \div 2(2 r+a)$ & \\
\hline $8 \times 9 \ldots$ & $O \div T=\pi r \div 2(2 r+a)$ & 69.80 \\
\hline (n) & $O \div T=\pi r \div 2(2 r+a)$ & 39.30 \\
\hline (1) & $O \div T=\pi r \div 2(2 r+a)$ & 19.60 \\
\hline $4 \times 18$. & $O \div T=\pi r \div 2(2 r+a)$ & 17.50 \\
\hline $2 \times 18$ & $O \div T=\pi r \div 2(2 r+a)$ & 8.70 \\
\hline
\end{tabular}

$* r=\frac{1}{2}$ vine distance; $a=$ row distance $-2 r ; O=$ area of root circle; $T=$ total area per vine. 
between the vines in the row increases. (See table 1 and fig. 1.) Whether the small difference between the hexagonal and square system is of any importance is doubtful, but there is very probably a retardation of development and a loss of crop, at least for some years, with the avenue system.

\section{EXPERIMENTAL METHOD}

Numerous accounts of experiments to determine the relation of density and arrangement to the quantity and quality of the vintage have appeared in viticultural literature during the past forty years, but the results have in most cases been doubtful owing to a failure to eliminate or equalize complicating conditions of soil, variety, or injurious effects of pests, diseases, or unfavorable weather.

Plan of the Experiment.-In order to obtain evidence on this problem, under normal or usual conditions of grape growing in California, an experiment was started at Davis in 1923 and continued until 1930, when it was abandoned on account of the invasion of the $4 \times 4$ Black Prince plots by phylloxera. All the $4 \times 4$ vines including the Muscat were removed in 1928. Fortunately, four crops, those of 1925, 1926, 1927, and 1928, were obtained except from blocks A and B in 1928. During the last three of these crop years it is probable that the hypothetical competition had begun among the more closely planted vines. The data obtained therefore should throw light on some of the effects of the various densities and arrangements tested.

The plan of the experiment was to limit the inquiry to the effects of variations of density and of arrangement on a variety with great capacity for growth and on a variety with moderate capacity, all other conditions being as uniform and favorable as possible.

The strong-growing variety chosen was the Black Prince and the weaker the Muscat of Alexandria. The soil of the experiment plot is fertile, deep, well supplied with water, and very uniform. The climatic conditions are favorable.

The details of planting are shown in figure 1.

The densities and arrangements chosen represent the commoner practices in use in California (plots C, D, and G), and extensions of these practices in the direction of greater density (plots $\mathrm{A}, \mathrm{B}, \mathrm{F}$, and $\mathrm{H}$ ), and of less density (plot E). They also include variations in the arrangement of the avenue plantings in the direction of widening the avenue with the same density -i.e., reducing the distance between the vines in the row and increasing correspondingly the distance between rows 
(plots G, I, F, and H). The intention is to pass in each direction beyond the probable optimum of density and arrangement in order to be sure of including the optimum.

The treatment of all plots was as nearly as possible identical in the matters of cultivation, pruning, and other operations, except that the vines in the avenue system were trellised and cordon-pruned and that irrigation was applied to each plot according to need.

Data Collected.-The data collected were the crop, the circumference of the trunk, the weight of the prunings for each vine and each year, and finally the weight of each vine when removed at the conclusion of the experiment. From this material it is possible to obtain directly or to compute approximately the rate of growth and total size of the vine and the rate of increase and total weight of the crop.

With these results the influence of the variations in density, arrangement, and variety of vine can be estimated as illustrated by figures 2 , 3 , and 4 and the corresponding tables.

\section{GROWTH OF THE VINES}

Figure 2 shows the variations in rapidity of development and in total growth during the eight years of the experiment, resulting from variations in density, arrangement, and variety of vine.

Variety.-The Black Prince exceeded the Muscat in all parallel cases. The mean total growth of all the Muscat vines in the plots planted in squares was only 47 per cent of that of the Black Prince planted in the same way and only 40 per cent in the plots planted in the avenue system. This indicates a relative capacity for growth under the conditions of the experiment of 43.5 for the Muscat of Alexandria as compared to 100 for the Black Prince.

Arrangement.-An estimate of the influence of arrangement can be made by comparing plots $\mathrm{C}, \mathrm{G}$, and $\mathrm{I}$, each with a density of 605 vines to the acre but with planting arrangements of $8 \times 9,6 \times 12$, and $4 \times 18$ respectively; and of plots $\mathrm{B}, \mathrm{F}$, and $\mathrm{H}$, each with a density of 1,210 vines to the acre but arranged $6 \times 6,3 \times 12$, and $2 \times 18$ respectively.

Table 3 shows diminished growth with each increase in the difference in the distance between rows and in the distance between vines in the row. This restriction of growth is greater with the Muscat than with the Black Prince and is fairly regular in each case. It is an average of 29 per cent for the Black Prince and 45 per cent for the Muscat. This is much less than the hypothetical loss, which averages 71 per cent, and indicates that the theoretical loss due to competition is exaggerated or 
TABLE 2

GROWTH OF VINES, 1923-1930

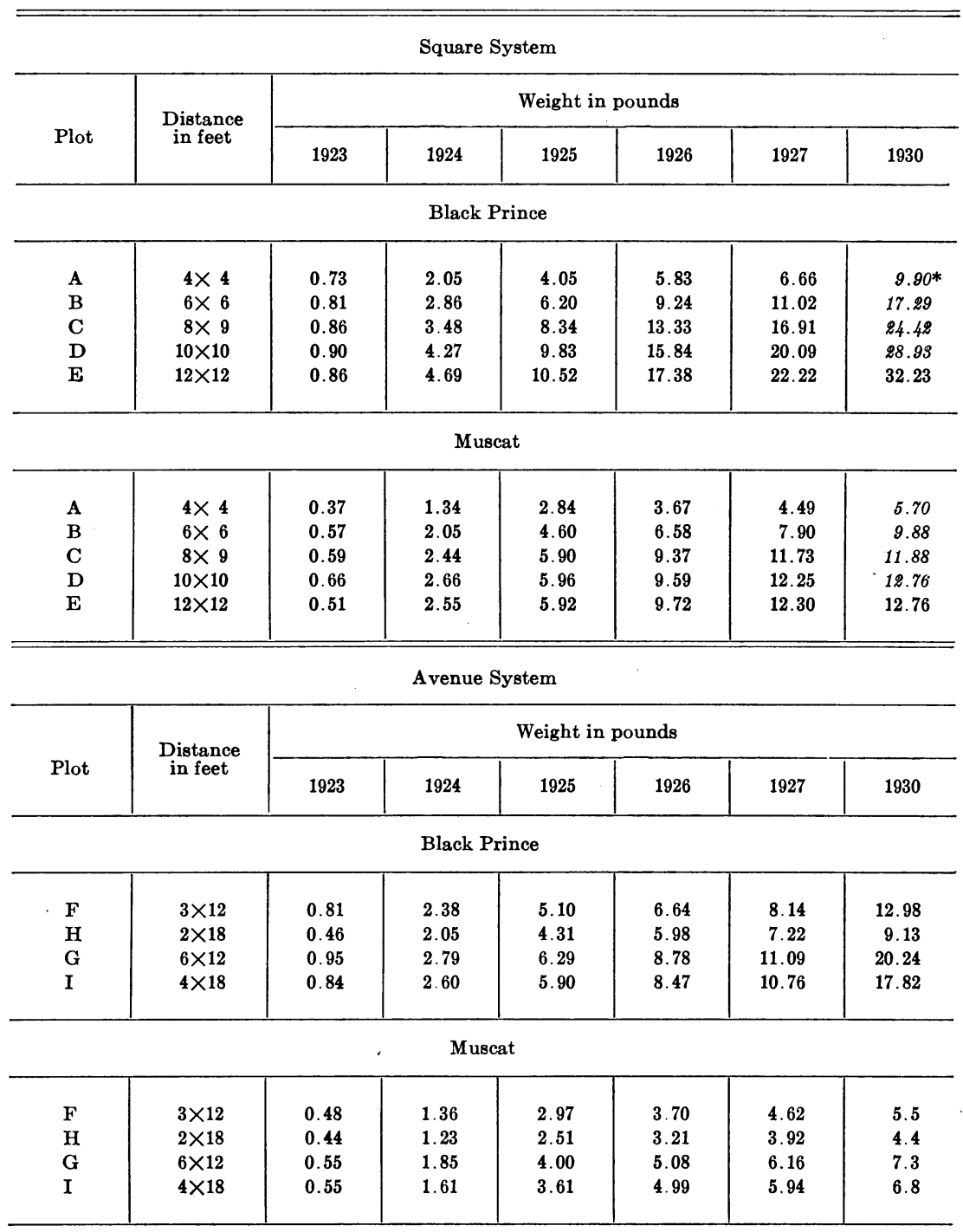

*Italic figures are estimates based on the weighings of the other plots. Other figures in 1930 are actual weighings. 
that competition has not reached its maximum at eight years. It is probable that each of these suppositions accounts for part of the difference.

Density.-The influence of the density of population is shown by plots A, B, C, D, and E all planted with the square arrangement.
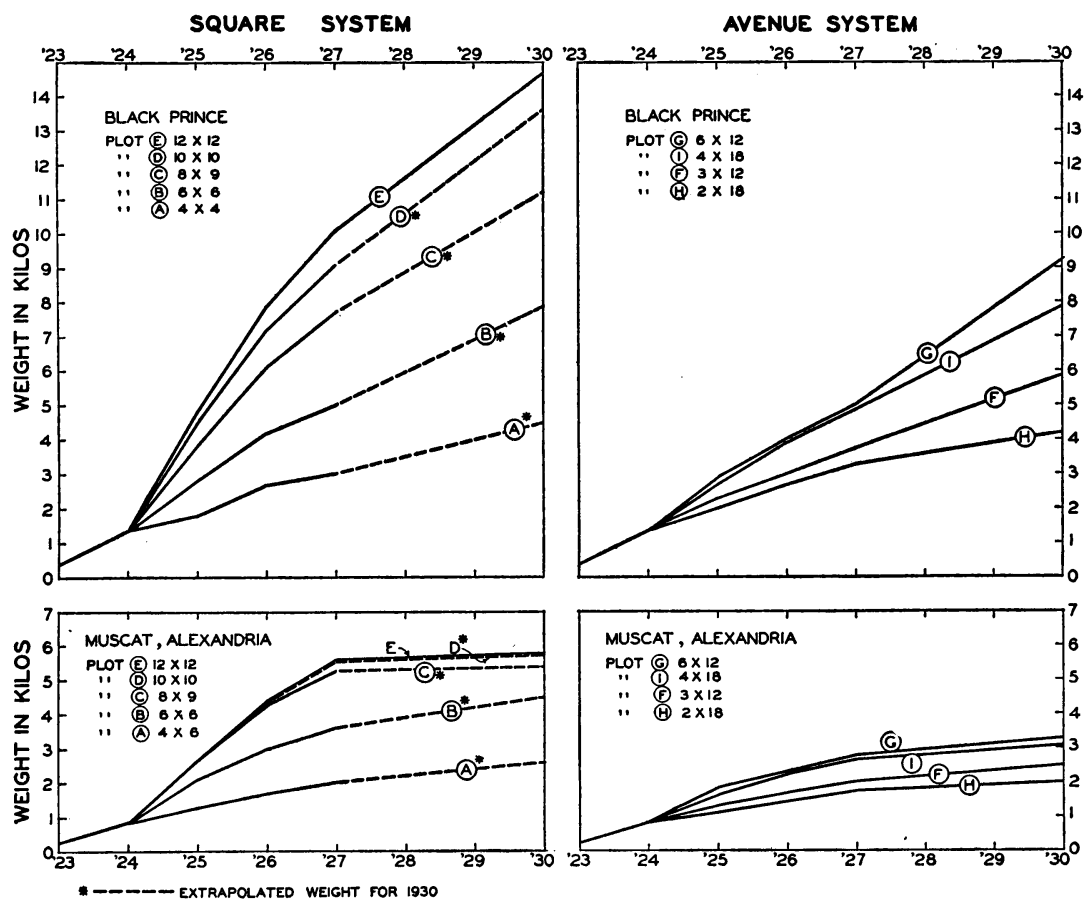

Fig. 2. Growth of vines, 1923-1930.

Table 4 shows an uninterrupted decrease in weight of vine with increase in number of vines per acre, with both varieties. The decrease is very regular with the Black Prince and follows a curve very close to that of decrease in distance between vines, indicating that competition between the vines had begun at least in the eighth year in the $10 \times 10$ plot and at increasingly earlier dates in the denser plots. With the Muscat, competition does not appear to have begun in the eighth year at lower densities than $8 \times 9$ or $6 \times 6$, and the decrease of weight of vine is much less than with the Black Prince. The slower growth of the Muscat has evidently delayed the start of competition and has perhaps obviated it in the wider spacings. The superior vigor and more rapid development of the Black Prince fit it better for the wider spaces. It has made 152 
per cent more growth than the Muscat in the widest spacing but only 75 per cent more in the narrowest.

The assumption that the size of the vines will finally be proportional to the available space allotted to each vine is probably approximately true within limits when all other conditions are equal. If this assumption is true for the conditions and limits of this experiment, the point of com.

TABLE 3

Influence of ArRangements of Vines on Growth

\begin{tabular}{|c|c|c|c|c|c|c|c|c|}
\hline \multirow{3}{*}{ Plot } & \multirow{3}{*}{$\begin{array}{l}\text { Distance } \\
\text { in feet }\end{array}$} & \multirow{3}{*}{$\begin{array}{l}\text { Density, } \\
\text { in vines } \\
\text { per acre }\end{array}$} & \multicolumn{4}{|c|}{ Average weight per vine at eight years } & \multirow{3}{*}{$V d^{*}$} & \multirow{3}{*}{$(V d)^{2 \dagger}$} \\
\hline & & & \multicolumn{2}{|c|}{ Black Prince } & \multicolumn{2}{|c|}{ Muscat } & & \\
\hline & & & Pounds & $\begin{array}{l}\text { Per cent } \\
\text { of plot in } \\
\text { square } \\
\text { system }\end{array}$ & Pounds & $\begin{array}{l}\text { Per cent } \\
\text { of plot in } \\
\text { square } \\
\text { system }\end{array}$ & & \\
\hline $\mathbf{C}$ & $8 \times 9 \ddagger$ & 605 & 24.42 & 100 & 11.88 & 100 & 100 & 100 \\
\hline G & $6 \times 12$ & 605 & 20.24 & 83 & 7.26 & 61 & 75 & 56 \\
\hline I & $4 \times 18$ & 605 & 17.82 & 73 & 6.82 & 57 & 50 & 25 \\
\hline $\mathbf{B}$ & $6 \times 6$ & 1210 & 17.29 & 100 & 9.88 & 100 & 100 & 100 \\
\hline $\mathbf{F}$ & $3 \times 12$ & 1210 & 12.98 & 75 & 5.50 & 56 & 50 & 25 \\
\hline $\mathbf{H}$ & $2 \times 18$ & 1210 & 9.13 & 53 & 4.40 & 45 & 33 & 11 \\
\hline
\end{tabular}

* $V d=$ The theoretical percentage of the plot in the square system if growth varied as the distance between vines in the row.

$\dagger(V d)^{2}=$ The theoretical percentage of the plot in the square system if growth varied directly with the soil area per vine, i.e., with the square of the distance between vines in the row.

$\ddagger$ The variation of $8 \times 9$ from the square is neglected.

plete utilization of the space for all plots had not yet been reached; for although the vines in the wider plantings are larger in virtually all cases, they have not yet reached the size represented by the available space.

\section{CROP PER VINE AND CROP PER ACRE}

If the mean crop per vine varied inversely as the number of vines per acre, the crop per acre would be constant. It seems probable that within certain limits of density, varying with the conditions of soil, climate, and variety, this will be true when the vines reach the stage of development where they are utilizing fully the available space. This stage will be the more remote the wider the spacing; and if the spacing is so wide that its utilization is beyond the capacity of the variety, the maximum crop possible with closer spacing will not be attained. For densities which allow the vines to utilize all the available space, but which are not so dense as to crowd the vines and thus interfere with the supply of 
light and air needed for growth and production, it is probable that the crops would finally vary little in volume. The increase of crop per vine for the two varieties and the nine plots during the four years of bearing is shown in figure 3 .

Square System.-With the Black Prince, after the first crop, the wider spacings gave the larger yields per vine in all the square-planted plots. The difference was noticeable in the first commercial crop and continued during the life of the experiment. This indicates that competition between adjacent vines, which was evident in the third year

TABLE 4

Influence of Density of Planting on Growth of Vine

\begin{tabular}{|c|c|c|c|c|c|c|c|c|}
\hline \multirow{3}{*}{ Plot } & \multirow{3}{*}{$\begin{array}{l}\text { Dinstance } \\
\text { in feet }\end{array}$} & \multirow{3}{*}{$\begin{array}{l}\text { Density, } \\
\text { in vines } \\
\text { per acre }\end{array}$} & \multicolumn{4}{|c|}{ Average weight per vine at eight years } & \multirow{3}{*}{$V d^{*}$} & \multirow{3}{*}{$(V d)^{2}$} \\
\hline & & & \multicolumn{2}{|c|}{ Black Prince } & \multicolumn{2}{|c|}{ Muscat } & & \\
\hline & & & Pounds & $\begin{array}{l}\text { Per cent of } \\
\text { plot } E\end{array}$ & Pounds & $\begin{array}{l}\text { Per cent of } \\
\text { plot E }\end{array}$ & & \\
\hline $\mathbf{E}$ & $12 \times 12$ & 303 & 32.25 & 100 & 12.76 & 100 & 100 & 100 \\
\hline $\mathbf{D}$ & $10 \times 10$ & 435 & 28.93 & 89 & 12.76 & 100 & 83 & 70 \\
\hline $\mathbf{C}$ & $8 \times 9$ & 605 & 24.42 & 76 & 1188 & 92 & 71 & 50 \\
\hline B & $6 \times 6$ & 1210 & 17.29 & 54 & 9.88 & 76 & 50 & 25 \\
\hline $\mathbf{A}$ & $4 \times 4$ & 2722 & 9.90 & 31 & 5.70 & 45 & 33 & 11 \\
\hline
\end{tabular}

$* V d=$ The theoretical percentage of plot $\mathrm{E}$ if growth varied as the distance between vines. per vine.

$\dagger(V d)^{2}=$ The theoretical percentage of plot $\mathrm{E}$ if growth per vine varied directly with the soil area

(1925) by the growth of the vines (fig. 2) affected the crop notably the fourth year. With the Muscat a distinct increase of crop per vine occurred only up to the $8 \times 9$ plot, the crop of which was virtually identical with those of the $10 \times 10$ and $12 \times 12$ plots up to the fifth year (1927) and showed little difference in the sixth. This indicates that the relatively small-growing Muscat had nearly or quite reached its fullest development in the $8 \times 9$ plot, while the stronger-growing Black Prince was still profiting by the increased space up to at least the $10 \times 10$ plot. The crops of all square-planted plots were slightly smaller in the sixth year than in the fifth, owing to a less favorable season. The widest plantings of the Muscat as well as those of the Black Prince apparently suffered less than the closest, indicating perhaps that there existed some competition even in the widest planting, though this is hardly evident in the growth. The mean weight of the Muscat vines in 1930 (fig. 2) showed little increase in the wider plantings due to greater soil area per vine, being $5.4,5.8$, and 5.8 in plots $8 \times 9,10 \times 10$, and $12 \times 12$, respectively. The increases in weights of the Black Prince vines in corresponding plots were somewhat larger-11.1, 13.6, and 14.7; or in per- 
centages, 100, 107, and 107 for Muscat, and 100, 123, and 132 for Black Prince.

This seems to indicate that for the conditions of soil, climate, and treatment of the experiment, the Muscat would give its maximum crop per vine with a density of about 600 vines to the acre arranged in squares, but that the Black Prince under the same conditions would still increase its mean crop per vine with a density of 300 or lower.
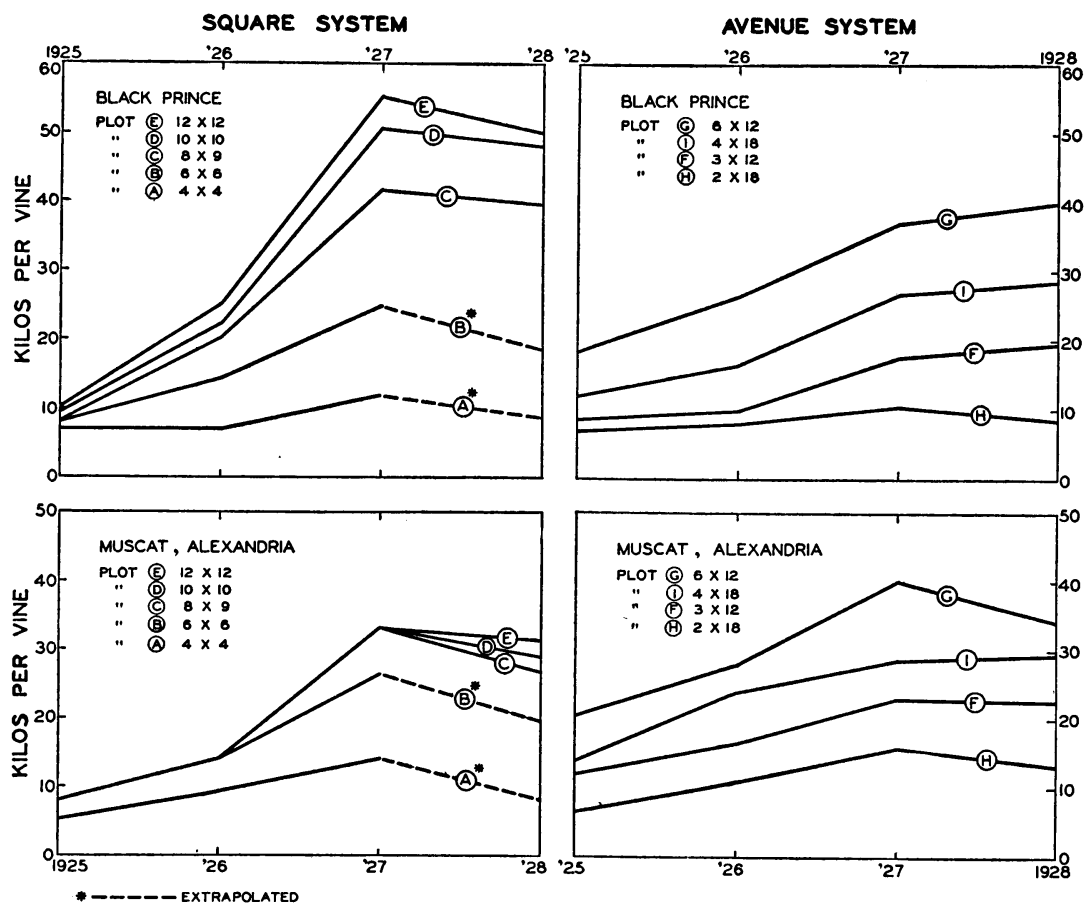

Fig. 3. Increase of crop per vine, 1925-1928.

The increased crop per vine was in no case sufficient to compensate entirely for the smaller number of vines. With 2,722 vines to the acre, the Black Prince yielded in the four crops 47.1 tons per acre though the mean total crop per vine for the four years was only 34.6 pounds, while with 303 vines per acre and a mean total crop per vine of 140.4 pounds, it yielded only 21.3 tons. This is an increased vine yield of over 300 per cent and a decreased acre yield of 55 per cent.

With the Muscat the corresponding figures are : with 2,722 vines, 50.6 tons per acre and 37.2 pounds per vine, and with 300 vines, 12.8 tons per acre and 84.9 pounds per vine, or a gain of 128 per cent in crop per vine and a loss of 75 per cent in crop per acre for the wider spacing. 
This comparison undoubtedly exaggerates the loss of crop due to the lower vine concentrations because the more populous plots had more nearly reached their maximum crops than the less populous. A better comparison is that shown in table 6 where it can be seen that the loss of

TABLE 5

INCREASE OF CROP PER VINE, 1925-1928

\begin{tabular}{|c|c|c|c|c|c|c|c|c|}
\hline \multirow{2}{*}{ Plot } & \multirow{2}{*}{$\begin{array}{l}\text { Distance, } \\
\text { in feet }\end{array}$} & \multirow{2}{*}{$\begin{array}{l}\text { Density, } \\
\text { in vines } \\
\text { per acre }\end{array}$} & \multicolumn{4}{|c|}{ Annual crop, in pounds per vine } & \multicolumn{2}{|c|}{ Total crop } \\
\hline & & & 1925 & 1926 & 1927 & 1928 & $\begin{array}{l}\text { Pounds } \\
\text { per vine }\end{array}$ & $\begin{array}{c}\text { Tons } \\
\text { per acre }\end{array}$ \\
\hline \multicolumn{9}{|c|}{ Black Prince in square system } \\
\hline $\begin{array}{l}\mathrm{E} \\
\mathrm{D} \\
\mathrm{C} \\
\mathrm{B} \\
\mathrm{A}\end{array}$ & $\begin{array}{r}12 \times 12 \\
10 \times 10 \\
8 \times 9 \\
6 \times 6 \\
4 \times 4\end{array}$ & $\begin{array}{r}303 \\
435 \\
605 \\
1,210 \\
2,722\end{array}$ & $\begin{array}{r}10.0 \\
9.4 \\
8.1 \\
9.2 \\
7.0\end{array}$ & $\begin{array}{r}25.0 \\
22.6 \\
19.5 \\
14.1 \\
7.1\end{array}$ & $\begin{array}{l}55.2 \\
50.1 \\
41.3 \\
24.7 \\
11.8\end{array}$ & $\begin{array}{r}50.2 \\
47.7 \\
39.2 \\
18.5 \\
8.8\end{array}$ & $\begin{array}{r}140.4 \\
129.8 \\
108.1 \\
66.5 \\
34.6\end{array}$ & $\begin{array}{l}21.3 \\
28.3 \\
32.8 \\
40.2 \\
47.1\end{array}$ \\
\hline \multicolumn{9}{|c|}{ Black Prince in avenue system } \\
\hline $\begin{array}{l}\text { G } \\
\text { I } \\
\text { F } \\
\text { H }\end{array}$ & $\begin{array}{l}6 \times 12 \\
4 \times 18 \\
3 \times 12 \\
2 \times 18\end{array}$ & $\begin{array}{r}605 \\
605 \\
1,210 \\
1,210\end{array}$ & $\begin{array}{r}20.5 \\
11.9 \\
9.2 \\
6.4\end{array}$ & $\begin{array}{r}26.2 \\
16.2 \\
9.5 \\
8.1\end{array}$ & $\begin{array}{l}36.6 \\
26.3 \\
17.4 \\
15.0\end{array}$ & $\begin{array}{l}39.6 \\
28.6 \\
19.4 \\
14.8\end{array}$ & $\begin{array}{r}120.9 \\
82.3 \\
56.4 \\
44.2\end{array}$ & $\begin{array}{l}36.6 \\
24.9 \\
34.1 \\
26.7\end{array}$ \\
\hline \multicolumn{9}{|c|}{ Muscat of Alexandria in square system } \\
\hline $\begin{array}{l}\mathrm{E} \\
\mathrm{D} \\
\mathrm{C} \\
\mathrm{B} \\
\mathrm{A}\end{array}$ & $\begin{array}{r}12 \times 12 \\
10 \times 10 \\
8 \times 9 \\
6 \times 6 \\
4 \times 4\end{array}$ & $\begin{array}{r}303 \\
435 \\
605 \\
1,210 \\
2,722\end{array}$ & $\begin{array}{l}6.6 \\
7.9 \\
9.0 \\
8.8 \\
5.9\end{array}$ & $\begin{array}{r}14.1 \\
15.4 \\
14.7 \\
14.1 \\
9.2\end{array}$ & $\begin{array}{l}32.8 \\
33.7 \\
33.0 \\
26.4 \\
14.1\end{array}$ & $\begin{array}{r}31.4 \\
29.1 \\
27.0 \\
19.7 \\
8.0\end{array}$ & $\begin{array}{l}84.9 \\
86.1 \\
83.7 \\
69.1 \\
37.2\end{array}$ & $\begin{array}{l}12.8 \\
18.7 \\
25.3 \\
41.8 \\
50.6\end{array}$ \\
\hline \multicolumn{9}{|c|}{ Muscat of Alexandria in avenue system } \\
\hline G & $6 \times 12$ & 605 & 21.0 & 27.5 & 39.9 & 34.2 & 122.6 & 37.1 \\
\hline $\mathbf{I}$ & $4 \times 18$ & 605 & 13.9 & 24.3 & 28.6 & 29.4 & 96.2 & 29.1 \\
\hline $\mathbf{F}$ & $3 \times 12$ & 1,210 & 12.1 & 16.3 & 22.9 & 22.5 & 73.8 & 45.1 \\
\hline $\mathbf{H}$ & $2 \times 18$ & 1,210 & 7.7 & 11.5 & 15.4 & 13.6 & 48.2 & 29.2 \\
\hline
\end{tabular}

crop from larger spacing is diminishing in all cases. It indicates that it might disappear entirely in a few years with the Black Prince in all plots.

With the Muscat, though the loss shows decrease, it appears unlikely that it would disappear entirely except in plot B and perhaps in plot C, under the conditions of this experiment. 
Avenue System.-In the plots arranged according to the square system there are two variable factors-variety and concentration. In the plots arranged according to the avenue system there is an additional

TABLE 6

Crop in Pounds per Vine and Tons Per ACre; Mean Crop, 1927-1928

\begin{tabular}{|c|c|c|c|c|c|c|c|c|c|}
\hline \multirow{3}{*}{ Plot } & \multirow{3}{*}{$\begin{array}{l}\text { Density, } \\
\text { in vines } \\
\text { per acre }\end{array}$} & \multicolumn{4}{|c|}{ Black Prince } & \multicolumn{4}{|c|}{ Muscat } \\
\hline & & \multicolumn{2}{|c|}{$\begin{array}{c}\text { Mean yield, } \\
1927-1928\end{array}$} & \multicolumn{2}{|c|}{$\begin{array}{l}\text { Per cent of crop } \\
\text { in plot } \mathbf{A}\end{array}$} & \multicolumn{2}{|c|}{$\begin{array}{c}\text { Mean yield, } \\
1927-1928\end{array}$} & \multicolumn{2}{|c|}{$\begin{array}{l}\text { Per cent of crop } \\
\text { in plot } A\end{array}$} \\
\hline & & $\begin{array}{l}\text { Pounds } \\
\text { per vine }\end{array}$ & $\begin{array}{c}\text { Tons } \\
\text { per acre }\end{array}$ & $\begin{array}{l}1927- \\
1928\end{array}$ & $\begin{array}{l}1925- \\
1928\end{array}$ & $\begin{array}{l}\text { Pounds } \\
\text { per vine }\end{array}$ & $\begin{array}{c}\text { Tons } \\
\text { per acre }\end{array}$ & $\begin{array}{l}1927- \\
1928\end{array}$ & $\begin{array}{l}1925- \\
1928\end{array}$ \\
\hline $\mathbf{E}$ & 303 & 52.7 & 8.0 & 57 & 45 & 32.1 & 4.9 & 32 & 25 \\
\hline D & 435 & 48.9 & 10.6 & 76 & 60 & 31.4 & 6.8 & 45 & 37 \\
\hline $\mathbf{C}$ & 605 & 40.3 & 12.2 & 87 & 70 & 31.0 & 9.4 & 62 & 50 \\
\hline B & 1,210 & 21.6 & 13.1 & 94 & 85 & 23.1 & 14.0 & 93 & 82 \\
\hline $\mathbf{A}$ & 2,722 & 10.3 & 14.0 & 100 & 100 & 11.1 & 15.1 & 100 & 100 \\
\hline
\end{tabular}

TABLE 7

Comparison of Crops per ACre with Different Arrangements and with Head and Cordon Pruning

\begin{tabular}{|c|c|c|c|c|c|c|c|c|c|c|}
\hline \multirow{3}{*}{ Plot } & \multirow{3}{*}{$\begin{array}{l}\text { Distance } \\
\text { in feet }\end{array}$} & \multirow{3}{*}{$\begin{array}{l}\text { Density, } \\
\text { in vines } \\
\text { per acre }\end{array}$} & \multicolumn{4}{|c|}{ Black Prince } & \multicolumn{4}{|c|}{ Muscat } \\
\hline & & & \multicolumn{2}{|c|}{$\begin{array}{c}\text { Mean yield, } \\
1927-1928\end{array}$} & \multicolumn{2}{|c|}{$\begin{array}{l}\text { Yield per acre } \\
\text { in per cent of } \\
\text { square system* }\end{array}$} & \multicolumn{2}{|c|}{$\begin{array}{c}\text { Mean yield, } \\
1927-1928\end{array}$} & \multicolumn{2}{|c|}{$\begin{array}{l}\text { Yield per acre } \\
\text { in per cent of } \\
\text { square system* }\end{array}$} \\
\hline & & & $\begin{array}{l}\text { Pounds } \\
\text { per vine }\end{array}$ & $\begin{array}{c}\text { Tons } \\
\text { per acre }\end{array}$ & $\begin{array}{l}1927- \\
1928\end{array}$ & $\begin{array}{l}1925- \\
1928\end{array}$ & $\begin{array}{l}\text { Pounds } \\
\text { per vine }\end{array}$ & $\begin{array}{c}\text { Tons } \\
\text { per acre }\end{array}$ & $\begin{array}{l}1927- \\
1928\end{array}$ & $\begin{array}{l}1925- \\
1928\end{array}$ \\
\hline C & $8 \times 9 *$ & 605 & 40.3 & 12.2 & 100 & 100 & 30.0 & 9.1 & 100 & 100 \\
\hline G & $6 \times 12$ & 605 & 38.1 & 11.5 & 94 & 112 & 37.0 & 11.2 & 123 & 147 \\
\hline I & $4 \times 18$ & 605 & 27.5 & 8.3 & 68 & 76 & 29.0 & 8.8 & 97 & 115 \\
\hline B & $6 \times 6$ & 1,210 & 31.6 & 13.1 & 100 & 100 & 23.0 & 13.9 & 100 & 100 \\
\hline $\mathbf{F}$ & $3 \times 12$ & 1,210 & 18.4 & 11.1 & 85 & 85 & 22.7 & 13.7 & 98 & 108 \\
\hline $\mathrm{H}$ & $2 \times 18$ & 1,210 & 14.9 & 9.0 & 69 & 66 & 14.5 & 8.8 & 64 & 70 \\
\hline
\end{tabular}

* Variation of $8 \times 9$ from the square system is neglected.

variable - the method of pruning. In the square-system plots, the vines were head pruned, in the avenue system they were cordon pruned. We have thus two variables of opposing character- $(a)$ increasing nearness of the vines in the row which tends to diminish the crop, and $(b)$ cordon pruning which tends to increase it. ${ }^{4}$ Table 7 is arranged to show the effect of the three variables.

If we compare the yields of the last two crops of the Black Prince in plots $G$ and I of the avenue system with the yields for the same crops in

4 At least with young vines. 
plot $C$ of the square system -all with the same vine concentration of 605 vines to the acre-we find that plot G arranged $6 \times 12$ has produced a crop 6 per cent less than plot $C$ arranged $8 \times 9$ or virtually of the same amplitude; while in plot I arranged $4 \times 18$ the crop is 32 per cent less. This indicates that the restriction of crop due to narrowing the vine distance from 8 to 6 is compensated for by the augmentation of the crop due to cordon pruning. In plot I, however, the narrowing of vine distance from 8 to 4 has reduced the crop 32 per cent even with the augmentation presumably caused by cordon pruning. Comparing in the same way avenue plots $\mathrm{F}$ and $\mathrm{H}$ cordon pruned with the square plot $\mathrm{B}$ head pruned, all of concentration 1,210 to the acre, we find the narrowing of vine distance from 6 to 3 has reduced the crop 15 per cent and a narrowing from 6 to 2,31 per cent, notwithstanding the cordon pruning.

Comparing the Muscat plots in the same way we find that the Muscat has been less unfavorably affected by narrowing the vine distances. The restriction of crop by narrowing the vine distance from 8 to 6 combined with the augmentation due to cordon pruning has resulted in a net augmentation of crop of 23 per cent, while narrowing from 8 to 4 and from 6 to 3 have had virtually no net effect on the weight of crop. The net reduction of narrowing from 6 to 2 , however, is 36 per cent.

These differences from the results with the Black Prince seem to indicate that the Muscat benefited more from cordon pruning than the Black Prince or that it failed to benefit as much as the stronger-growing Black Prince from the wider vine distances. Probably both factors are involved.

\section{SUMMARY AND CONCLUSION}

The object of this experiment was to determine the influence on the fruitfulness of vines of their density and arrangement in the vineyard under identical and favorable conditions of growth.

Density.-It was found that under the climatic and cultural conditions of the vineyard at Davis the yield per vine at the first crop (in 1925, the third year after planting) was little, if at all, affected by the density. At all planting distances tested, from $4 \times 4 \mathrm{ft}$. to $12 \times 12 \mathrm{ft}$., either with the very vigorous Black Prince or with the more moderate Muscat of Alexandria, the first yield per vine was virtually the same. The first crop per acre, therefore, varied almost exactly with the density (the number of vines per unit area). With each subsequent crop up to 1928 the yield per vine, and therefore per acre, increased at all densities, but more rapidly with the wider spacings than with the closer (table 8).

As shown in table 8 , the advantage of the closer plantings diminished 
with time. In the 1925 crop, the yield per acre of the $4 \times 4$ planting of Black Prince was 6.3 times that of the $12 \times 12$ planting; and that of the $4 \times 4$ planting of Muscat, 8.0 times that of the $12 \times 12$. These differences gradually diminished until in 1927-1928 the corresponding ratios were 1.8 for the Black Prince and 3.1 for the Muscat. The ratio of increase in acre crop (i.e., the ratio of the 1927-1928 crop to the 1925 crop) was progressively higher with the wider spacing up to and including the $10 \times 10$ with Black Prince and the $12 \times 12$ with Muscat.

TABLE 8

InCRease of Yield Per ACre in the First Four Crops at Various Densities (Square system)

\begin{tabular}{|c|c|c|c|c|c|c|}
\hline Variety and crop & $4 \times 4$ & $6 \times 6$ & $8 \times 9$ & $10 \times 10$ & $12 \times 12$ & $\underset{4 \times 12}{\text { Ratio, }} \underset{4 \times 4}{\text { to }}$ \\
\hline Black Prince & 9.5 & \multirow[b]{2}{*}{5.6} & & & \multirow[b]{2}{*}{1.5} & 6.3 \\
\hline $\begin{array}{l}\text { 1925, in tons per acre } \\
\text { Mean, } 1927-1928, \text { tons per } \\
\text { acre }\end{array}$ & \multirow{2}{*}{$\begin{array}{c}14.0 \\
1.47\end{array}$} & & 2.5 & 2.0 & & \multirow{2}{*}{$\begin{array}{r}1.8 \\
\ldots \ldots . .\end{array}$} \\
\hline Ratio $1927-1928$ to $1925 \ldots \ldots$ & & $\begin{array}{c}13.0 \\
2.32\end{array}$ & $\begin{array}{l}12.2 \\
4.87\end{array}$ & $\begin{array}{c}10.6 \\
5.32\end{array}$ & $\begin{array}{l}7.8 \\
5.28\end{array}$ & \\
\hline Muscat & \multirow{3}{*}{$\begin{array}{c}8.0 \\
15.1 \\
1.89\end{array}$} & \multirow[b]{2}{*}{5.3} & \multirow[b]{2}{*}{2.7} & \multirow[b]{2}{*}{1.7} & & \multirow[b]{2}{*}{8.0} \\
\hline $\begin{array}{l}1925, \text { in tons per acre } \ldots \ldots . . . . \\
\text { Mean, } 1927-1928, \text { tons per }\end{array}$ & & & & & & \\
\hline acre $\ldots$ & & 14.0 & 9.1 & 6.9 & $4.9^{\circ}$ & 3.1 \\
\hline
\end{tabular}

It seems probable, from the trends indicated, that the differences in acre crop would in time disappear with the Black Prince or even be reversed in sign at these densities. With the Muscat, the approach to equality of acre crop was slower than with the Black Prince and indicates that the yield of the widest plantings, $10 \times 10$ and $12 \times 12$, might never equal that of the greater densities or at least would require many years.

These results suggest that under the conditions of the Davis vineyard, densities of from 300 to 500 vines to the acre, with the square system of planting, are suitable for obtaining maximum crops with Black Prince and similar strong-growing varieties. For Muscat and other moderate growers, the production of the largest crops would require about 600 vines to the acre, and perhaps more for weaker-growing varieties. The gain in larger crops with greater densities than these is evanescent and, under the conditions of this experiment, which are typical of a large part of the grape-growing regions of California, would usually be more than neutralized finally by loss due to the extra cost of vineyard work of all kinds-pruning, staking, tying, cultivation, irrigation, distribu- 
tion of manure and boxes, and the handling of the grapes during harvesting.

Arrangement.-The influence on the crop of different arrangements of the vines where the density of planting was the same is shown in table 9 and figure 4, Sections III and IV.

With a density of 605 the yield per vine of the Black Prince at the first crop was 20.5 pounds in the $6 \times 12$ plot and 11.9 pounds in the $4 \times 18$ plot, or a decrease of 42 per cent due to the reduction of the vine

TABLE 9

Crop in Pounds per Vine, with Various ARRangements

\begin{tabular}{|c|c|c|c|c|c|c|c|}
\hline \multirow{3}{*}{ Variety } & \multirow{3}{*}{ Year } & \multicolumn{3}{|c|}{ Density 605 vines per acre } & \multicolumn{3}{|c|}{ Density 1,210 vines per acre } \\
\hline & & \multirow{2}{*}{$\begin{array}{l}\text { Square } \\
\text { system } \\
8 \times 9\end{array}$} & \multicolumn{2}{|c|}{ Avenue system } & \multirow{2}{*}{$\begin{array}{c}\text { Square } \\
\text { system } \\
6 \times 6\end{array}$} & \multicolumn{2}{|c|}{ A venue system } \\
\hline & & & $6 \times 12$ & $4 \times 18$ & & $3 \times 12$ & $2 \times 18$ \\
\hline Black Prince \{ & $\begin{array}{l}1925 \\
1928\end{array}$ & $\begin{array}{r}8.1 \\
39.2\end{array}$ & $\begin{array}{l}20.5 \\
39.6\end{array}$ & $\begin{array}{l}11.9 \\
28.6\end{array}$ & $\begin{array}{r}9.2 \\
18.5\end{array}$ & $\begin{array}{r}9.2 \\
19.4\end{array}$ & $\begin{array}{r}6.4 \\
14.8\end{array}$ \\
\hline Muscat............ & $\begin{array}{l}1925 \\
1928\end{array}$ & $\begin{array}{r}9.0 \\
27.0\end{array}$ & $\begin{array}{l}21.0 \\
34.0\end{array}$ & $\begin{array}{l}13.9 \\
29.4\end{array}$ & $\begin{array}{r}8.8 \\
197\end{array}$ & $\begin{array}{l}121 \\
22.5\end{array}$ & $\begin{array}{r}7.7 \\
13.6\end{array}$ \\
\hline
\end{tabular}

distance from 6 to 4 , or 33 per cent. With the Muscat the corresponding figures are 21 pounds in the $6 \times 12$ plot and 13.9 pounds in the $4 \times 18$ plot, or a decrease of 34 per cent.

With a density of 1,210 the yield per vine of the Black Prince was 9.2 pounds in the $3 \times 12$ plot and 6.4 pounds in the $2 \times 18$, a decrease of 30 per cent, and with the Muscat the corresponding figures are 12.1 pounds for the $3 \times 12$ plot and 7.7 pounds for the $2 \times 18$ plot, a decrease of 36 per cent; the reduction of the vine distance being from 3 to 2 or 33 per cent as with the 605 density.

With each variety therefore the decrease of yield per vine at the first crop was very close to the 33 per cent reduction in vine distance. With later crops the decrease of yield was less in the plots of density 605 , being 28 per cent with the Black Prince and 14 per cent with the Muscat at the fourth crop. In the plots of density 1,210, the decrease of yield was only slightly less with the Black Prince, 24 per cent, and with the Muscat the decrease was greater than with the first crop, or 40 per cent. A reduction of vine distance from 6 to 4 appears to have decreased the later crops of the Black Prince more than those of the Muscat, but a reduction in distance from 3 to 2 had an opposite effect, decreasing the crop of Muscat more than that of the Black Prince. A possible explanation of this difference is that the strong-growing Black Prince was better able to make use of the soil in the wide avenues than the weaker Muscat. 
The crops of the $8 \times 9$ and $6 \times 6$ plots given in table 9 are not directly comparable with the avenue plots because of the different system of pruning. The use of long canes in forming the cordons in the third year accounts for the heavier crops in the avenue plots. The spur pruning used the same year in forming the head restricted the crop of the squareplanted plots. By the fourth crop, however, the yields were not very

SQUARE SYSTEM
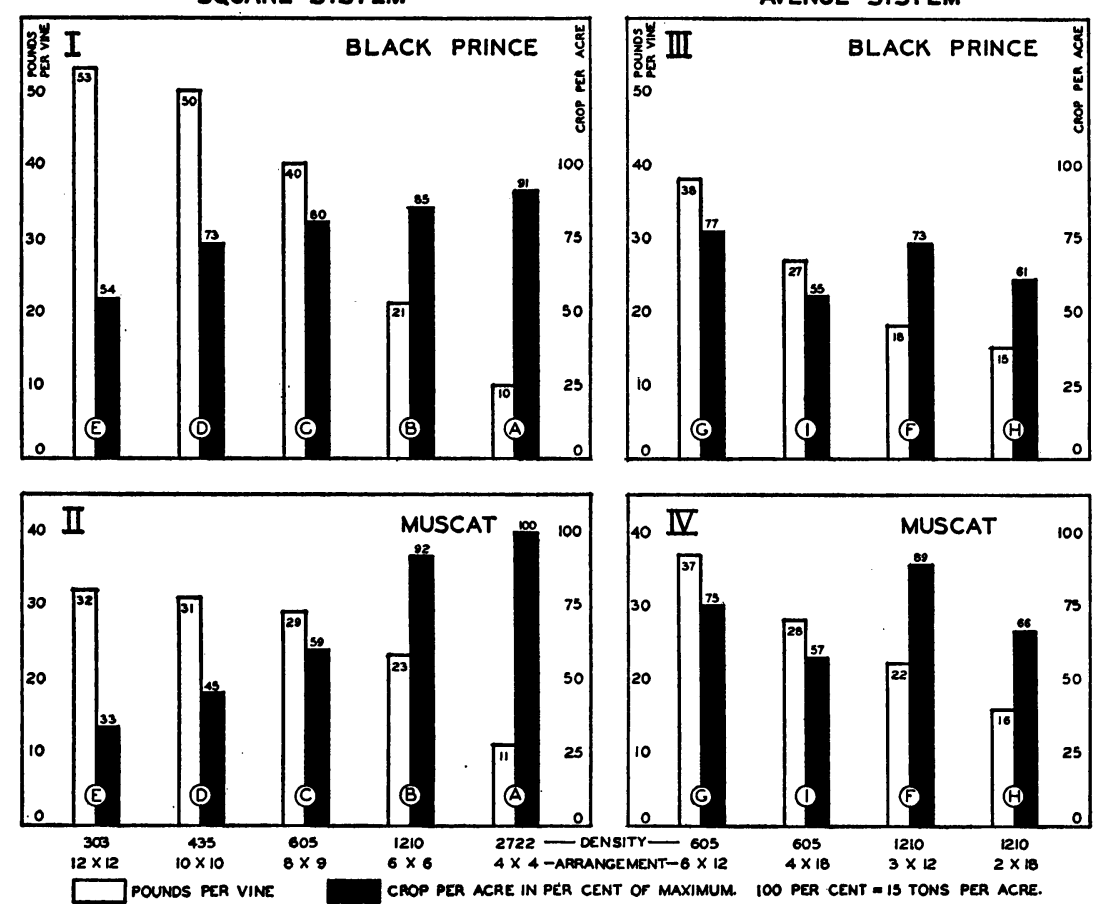

Fig. 4. Mean crop per acre and crop per vine, 1927-1928. Sections I and II show the square-system plots of the two varieties arranged in the order of increasing density. As the density increased, the crop per acre increased and the crop per vine decreased. In no case was the increase in vine crop sufficient to compensate entirely for the decrease in the number of vines.

Sections III and IV show the avenue-system plots of the two varieties. With each variety there were two sets of two plots each which were of equal density but differed from each other in vine arrangement. In plots of equal density the crop per acre and crop per vine both decreased as vine distance decreased.

different except for the closest vine distance of $2 \times 18$, which were from 20 to 30 per cent lower than those of the $6 \times 6$.

This shows that with the strong-growing Black Prince there was no loss of yield per acre by the avenue planting of $6 \times 12$ instead of $8 \times 9$ or of $3 \times 12$ instead of $6 \times 6$. With Muscat there was a notable increase in each case with the avenue system which, however, is probably due to 
the cordon pruning. A further reduction of vine distance to $4 \times 18$ caused a loss of about 38 per cent with the Black Prince as compared with the $8 \times 9$ plot, but had little effect with the Muscat. A reduction to $2 \times 18$, however, caused a loss of 20 per cent with the Black Prince, and 32 per cent with the Muscat, as compared with the $6 \times 6$ plots.

Too great a difference between the width of the avenue and the distance between the vines in the row causes a considerable reduction in vine yield and therefore in acre yield. Cordon pruning, at least for several of the first few crops, seems to be useful in neutralizing the reduction within limits which vary with the character of the vine variety.

Figure 4 illustrates the approach to maximum bearing made by the various plots. This maximum, under the conditions of the experiment, is assumed to be the mean crop of the $4 \times 4$ Muscat plot in the third and fourth years of bearing, or 15 tons per acre, taken as 100 per cent.

The acre crop of the Black Prince in the $12 \times 12$ plot is 54 per cent of the maximum and increases with each increase of density in the square plantings to 91 per cent in the $4 \times 4$ plot. The crop of the Muscat with 33 per cent in the $12 \times 12$ plot increases in a similar way to the 100 per cent in the $4 \times 4$ plot.

A curtailment of the crop due to the uneven distribution of the vines in the avenue systems is shown in virtually all cases and would have been greater if the spur pruning of the square-system plots had been used with the avenue plots.

It is plain that the arrangement of the vines by the avenue system restricts the crop for at least several years and the more seriously, the greater the departure from the square system. With time this restriction diminishes and with a moderate departure from the equal distribution of the square system may disappear. Any extreme departure, however, will in all probability involve a permanent loss of crop. 